Number 4

\title{
KADAR PROTEIN URIN PADA IBU HAMIL TRIMESTER II DAN III DI PUSKESMAS II DENPASAR BARAT
}

\author{
Luh Putu Yoga Arsani ${ }^{1}$, I Wayan Merta ${ }^{2}$, Cok Dewi Widhya HS $^{3}$
}

\begin{abstract}
The presence of excess level of protein in urine of pregnant women is one of the cause of preeclampsia, besides hypertension and edema. Women can caused many diseases such as Protein is wich found in urin of pregnant. Protein which found in urine of pregnant women can caused many diseases such as Some disease that can discover protein in pregnant women's urine are renal diseases (glomerulus or tubular disease) and non-renal diseases (heart disease, liver disease, fever, stress, diabetes militus, hypertension). This study was aimed to analyze the result of proteinuria level based on the examination from pregnant women's urine of second and third trimester in Puskesmas II Denpasar Barat. This research applied a descriptive survey and the amount of samples was probability sampling method with insidental sampling technique, the data were collected from 39 respondents during the period of February to May 2016.The sample were examined semi-quantitatively by using dipstick test. Results of the examination to 39 samples indicates that 29 urine samples $(74,36 \%$ ) was negative, seven urine samples $(17,95 \%)$ positive $1(+)$, two urine samples $(5,13 \%)$ positive $2(++)$ and one urine samples $(2,56 \%)$ positive $3(+++)$.
\end{abstract}

keywords: pregnant woment; protein urine level; second trimester; third trimester

\section{PENDAHULUAN}

Angka kematian yang berhubungan dengan ibu dan anak adalah Angka Kematian Ibu (AKI), Angka Kematian Neonatus (AKN), Angka Kematian Bayi (AKB), dan Angka Kematian Balita (AKABA)(Dinas Kesehatan Provinsi Bali, 2014) $)^{1}$

$\begin{array}{ll}\text { Menurut World } & \text { Health } \\ \text { Organization(WHO) pada tahun } \\ \text { 2010angka kematian ibu di dunia }\end{array}$

sebesar 287.000. WHO memperkirakan ada $\quad 500.000$ kematian ibu melahirkan di seluruh dunia setiap tahunnya, dan $99 \%$ penyumbangdari angka tersebut merupakan negara berkembang ${ }^{2}$. Persentase terjadinya AKI di

\footnotetext{
1.,2.,3., Jurusan Analis Kesehatan Poltekkes Denpasar Korespondensi : Luh Putu Yoga Arsani ${ }^{1}$, Jurusan Analis Kesehatan, Poltekes Denpasar, Jalan Sanitasi No. 1 Sidakarya, Denpasar-Bali 80224, Indonesia.

Telp. +62-361-710 527, Fax. +62-361-710 448

Email : meditoryjournal@gmail.com
} 
Indonesia yaitu akibat perdarahan 60-70\%, preeklamsia dan eklamsia $20-30 \%$, infeksi $10-20 \%^{3}$. Preeklamsia didefinisikan sebagai suatu sindrom klinis spesifik yang ditandai oleh tekanan darah $\geq 140 / 90$ mmHg pada 2 kali pemeriksaan dengan interval 6 jam disertai proteinuria $>300 \mathrm{mg} / 24$ jam atau pemeriksaan proteinuria dengan metode carik celup pada urin sewaktu dengan $\mathrm{h} \geq 1+$ pada usia kehamilan $\geq 20 \operatorname{minggu}^{4}$.

Preeklamsia dan eklamsiayang tidak ditangani dengan baik dapat mengakibatkan komplikasi terhadap janin maupun ibu. Komplikasi pada janin dapat berupa asfiksia, berat badan lahir rendah, maupun preterm infant ${ }^{5}$. Preeklamsia dan eklamsia terdiri atas tiga macam gejala yaitu hipertensi, proteinuria dan edema ${ }^{6}$.

Pemeriksaan proteinuria pada ibu hamil merupakan hal yang penting dalam mendiagnosis dan menentukan berat ringan preeklamsia. Berdasarkan hasil penelitian terhadap 30 sampel didapatkan hasil pemeriksaan proteinuria pada ibu hamil trimester III di Rumah Bersalin Bhakti Ibu
Semarang yaitu lima sampel negatif, 14 sampel positif negatif, sembilan sampel positif $+(1+)$, dan dua sampel positif $++(2+)^{7}$.tu 9 sampel negatif, 19 sampel positif $+(1+)$, dan 9 sampel positif $++(2+)^{7}$.

Menurut LaporanKegiatan KIA di Dinas Kesehatan Kota Denpasar pada tahun 2015, diketahui bahwa jumlah kasus tertinggi ibu hamil risiko tinggi (perdarahan, infeksi abortus, keracunan kehamilan, partus lama) yang ditangani di puskesmas wilayah Denpasar Barat ditemukan di Puskesmas II sebanyak 13kasus. Jumlah kasus tertinggi untuk ibu hamil risiko tinggi yang dirujuk ke rumah sakit juga ditemukan di Puskesmas II Denpasar Barat sebanyak $424 \quad$ kasus.Jumlah kunjungan di poli KIA Puskesmas II Denpasar Barat pada tahun 2015 tercatat sebanyak 1016 orang, hal ini menunjukan cukup tingginya pelayanan kesehatan ibu dan anak di puskesmas tersebut ${ }^{8}$.

Pemantauan kesehatan sangat terkait dengan pemeriksaanpemeriksaan yang ada di laboratorium, salah satunya adalah pemeriksaan protein urin pada ibu 
hamil. Berdasarkan permasalahan diatas peneliti tertarik untuk melakukan penelitian tentang kadar protein urin pada ibu hamil trimester II dan III di Puskesmas II Denpasar Barat.

\section{METODE}

a).Jenis penelitian deskriptif yaitu suatu penelitian yang dilakukan untuk mendiskripsikan atau menggambarkan suatu fenomena yang terjadi di dalam masyarakat ${ }^{9}$.Populasi adalah semua ibu hamil trimester II dan III di wilayah Puskesmas II Denpasar Barat.Sampel adalah sebagian atau wakil populasi yang diteliti ${ }^{10}$.Sampel pada penelitian kali ini populasi yang memenuhi kriteria inklusi yaitu bersedia menandatangani informed Urin pada Ibu Hamil Trimester II di consent,Ibu dengan usia kehamilan 13-40 minggu, berada di wilayah Puskesmas II Denpasar Barat

.Teknik pengambilan sampel menggunakan non probability sampling dilakukan secara Incidental Sampling, yaitu dilakukan pengambilan kasus atau responden yang kebetulan ada atau tersedia di suatu tempat serta dianggap cocok sebagai responden ${ }^{11}$. Data-data yang diperoleh dikelompokkan dalam bentuk tabel dan narasi kemudian dianalisis secara diskriptif yaitu menggambarkan apa adanya yaitu membandingkang hasil pemeriksaan dengan teori yang ada.

\section{HASIL DAN PEMBAHASAN}

\section{Hasil}

1.Hasil pemeriksaan protein urin pada ibu hamil trimester II

Berdasarkan pemeriksaan yang telah dilakukan terhadap $15 \mathrm{ibu}$ hamil trimester II di Puskesmas II Denpasar Barat diperoleh 3 orang $(20,00 \%)$ dengan protein urin positif $+(1)$.

Tabel 1: Hasil Pemeriksaan Protein Puskesmas II Denpasar Barat 


\begin{tabular}{lcc}
\hline Hasil Pemeriksaan Protein Urin & Jumlah (N) & Persentase (\%) \\
\hline Negatif $(-)$ & 12 & 80,00 \\
Positif $+(1+)$ & 3 & 20,00 \\
Positif $++(2+)$ & 0 & 0 \\
Positif $+++(3+)$ & 0 & 0 \\
Positif $++++(4+)$ & 0 & 0 \\
\hline \multicolumn{1}{c}{ Total } & 15 & 100 \\
\hline
\end{tabular}

2. Hasil pemeriksaan protein urin pada ibu hamil trimester III

Berdasarkan pemeriksaan yang telah dilakukan terhadap $24 \mathrm{ibu}$ hamil trimester III di Puskesmas II Denpasar Barat diperoleh hasil 7 orang $(29,27 \%)$ dengan hasil pemeriksaan protein urin positif.

Tabel 2 Hasil Pemeriksaan Protein Urin pada Ibu Hamil Trimester III di Puskesmas II Denpasar Barat

\begin{tabular}{|c|c|c|}
\hline Hasil Pemeriksaan Protein Urin & Jumlah (N) & Persentase $(\%)$ \\
\hline 1 & 2 & 3 \\
\hline Negatif (-) & 17 & 70,83 \\
\hline Positif $+(1+)$ & 4 & 16,67 \\
\hline Positif $++(2+)$ & 2 & 8,33 \\
\hline Positif $+++(3+)$ & 1 & 4,17 \\
\hline 1 & 2 & 3 \\
\hline Positif $++++(4+)$ & 0 & 0 \\
\hline Total & 24 & 100 \\
\hline
\end{tabular}

\section{Pembahasan}

\section{Kadar protein urin pada ibu hamil trimester II dan III}


Kehamilan merupakan suatu keadaan fisiologis, akan tetapi ada beberapa keadaan yang dapat menyebabkan kehamilan penuh dengan ancaman misalnya hasil bertemunya sperma dan ovum yang tidak menempel dengan sempurna ke rahim, kemungkinan pertumbuhan janin yang terhambat, berbagai penyakit ibu yang mengancam kehamilan, hingga proses kelahiran yang juga mempunyai risiko tersendiri. Salah satu penyakit yang sering mengancam kehamilan yaitu preeklamsia $^{12}$.

Terjadinya preeklamsia dapat diketahui dengan melakukan pemeriksaan protein dalam urin ibu hamil. Pada penelitian ini pemeriksaan protein urin bertujuan untuk mengetahui ada tidaknya protein dalam urin ibu hamil trimester II dan III di Puskesmas II Denpasar Barat yang hasilnya dinyatakan secara semi kuantitatif. Sampel yang digunakan adalah urin sewaktu yang dikeluarkan pada satu waktu yang tidak ditentukan dan diperlakukan dengan khusus.

Berdasarkan hasil pemeriksaan protein urin terhadap 39 ibu hamil trimester II dan III diperoleh $10(25,64 \%)$ sampel positif dan $29(74,36 \%)$ sampel negatif. Sampel positif ditemukan pada urin ibu hamil trimester II dan III dengan nilai yang cukup bervariasi antara lain tujuh sampel $(17,95 \%)$ positif + (1+), dua sampel $(5,13 \%)$ positif ++ $(2+)$ dan satu sampel $(2,56 \%)$ positif+++ (3+). Hasil ini sesuai dengan penelitian Febrianti (2008) terhadap 30 sampel didapatkan hasil pemeriksaan proteinuria pada ibu hamil trimester III di Rumah Bersalin Bhakti Ibu Semarang yaitu19 sampelnegatif, sembilan sampel positif $+(1+)$, dan dua sampe positif ++ (2+).sedangkan pada penelitian Kasmian (2010) terhadap 37 sampel di dapatkan hasil pemeriksaan proteinuria pada ibu hamil trimester II di bidan praktek swasta Citra Mulia Kudus yaitu 9 sampel negatif, 19 sampel positif + (1+), dan 9 sampel positif ++ (2+).Diagnosis preeklamsia ringan ditegakkan dengan kriteria minimum, yaitu tekanan darah $\geq 140 / 90 \mathrm{mmHg}$ setelah gestasi lebih dari 20 minggu dan proteinuria $\geq 300$ $\mathrm{mg} / 24$ jam atau $\geq+1$ pada dipstik. ${ }^{12}$

Berdasarkan hasil pemeriksaan protein urin dari 10 
orang ibu hamil dengan protein urin positif, ditemukan dua ibu hamil yang memiliki tekanan darah 140/100 mmHg dengan hasil protein urin positif $+++(3+)$ dan positif ++ (2+), sekaligus mengalami edema yang merupakan tanda ibu hamil mengalami preeklamsia. Apabila tekanan darah dan derajat proteinuria terus meningkatdapat mengancam keselamat ibu dan janin.

Preeklamsia dapat berakibat buruk baik pada ibu maupun janin yang dikandungnya. Komplikasi pada ibu berupa sindroma hemolysis, elevated liver enzyme, low platelet (HELLP), edema paru, gangguan ginjal, perdarahan, solusio plasenta bahkan kematian ibu. Komplikasi pada bayi dapat berupa kelahiran premature, gawat janin, berat badan lahir rendah atau intra uterine fetal death (IUFD). Disfungsi endotel dianggap berperan dalam patogenesis preeklamsia. Jika endotel mengalami gangguan oleh berbagai hal seperti stress oksidatif maupun paparan dengan sitokin inflamasi dan hiperkolesterolemia, maka fungsi pengatur menjadi abnormal dan disebut disfungsi endotel. Pada keadaan ini terjadi ketidakseimbangan substansi vasoaktif sehingga dapat terjadi hipertensi. Disfungsi endotel juga menyebabkan permeabilitas vaskular meningkat sehingga menyebabkan edema dan proteinuria. Berdasarkan adanya hipertensi, edema dan proteinuria disfungsi endotel memegang peranan pada patogenesis preeklamsia $^{12}$.

Pada penelitian yang telah dilakukan apabila ibu hamil tidak mengalami proteinuria, belum tentu ibu hamil tidak akan mengalami preeklamsia, ini dipengaruhi oleh multifaktor,periode 2006 - 2008 dengan 366 responden yang menyatakan bahwa didapatkan $12,84 \%$ kasus preeklamsia dengan proteinuria negatif. Proteinuria merupakan proses akhir preeklamsia $^{13}$.

2. Kadar protein urin ibu hamil trimester II dan III berdasarkan usia kehamilan

Pada pemeriksaan protein urin yang telah dilakukan terhadap 15 orang ibu hamil trimester II diperoleh hasil positif $+(1+)$ sebanyak 3 orang $(20,00 \%)$ sedangkan pada 24 orang ibu hamil trimester III diperoleh hasil positif + 
(1+) sebanyak 4 orang $(16,67 \%)$, positif $++(2+)$ sebanyak 2 orang $(8,33 \%)$, dan positif $+++(3+)$ sebanyak 1 orang $(8,33 \%)$. Hasil ini menunjukan ibu hamil trimester III lebih banyak kemungkinan mengalami preeklamsia dibandingkan ibu hamil trimester II Hal ini sesuai dengan hasil penelitian yang menyatakan bahwa lebih banyak ibu hamil trimester III mengalami preeklamsia dibandingkan dengan ibu hamil trimester II. Kondisi ini diduga karena reaktivitas vaskular dimulai umur 20 minggu, meskipun demikian hal ini terdeteksi umumnya pada kehamilan trimester II, sehingga pemeriksaan protein urin pada ibu hamil penting dimulai dari trimester $\mathrm{I}^{14}$.

Pada kehamilan trimester II pemantauan kehamilan lebih sering dilakukan, mengingat pertumbuhan kehamilan yang sangat pesat serta pentingnya memantaukemungkinan timbulnya suatu penyakit yang membahayakan kehamilan. Hal ini juga dilakukan lebih sering dimasa kehamilan trimester III guna memantau lebih teliti setiap pertumbuhan bayi dan kemungkinan yang terjadi pada ibu dan janin dalam persiapan menghadapi proses persalinan $^{15}$.

\section{Kadar protein urin ibu hamil}

trimester II dan III

\section{berdasarkan umur}

Dalam penelitian ini jumlah ibu hamil yang berisiko ( $<20$ tahun dan $>35$ tahun) sebanyak 10 orang sedangkan kelompok ibu hamil tidak berisiko (20-35 tahun) sebanyak 29 orang. Berdasarkan pemeriksaan protein urin yang telah dilakukan dari 10 ibu hamil umur berisiko, terdapat 2 orang dengan protein urin positif $^{16 .}$ Astuti(2015) menyatakan umur merupakan bagian dari status reproduksi yang penting. Umur berkaitan dengan peningkatan atau penurunan fungsi tubuh sehingga mempengaruhi status kesehatan seseorang. Usia yang baik untuk hamil adalah 20 sampai 35 tahun. Sedangkan usia yang berisiko mengalami preeklamsia adalah usia $<20$ tahun dan $>35$ tahun. Pada kehamilan $<20$ tahun, keadaan reproduksi yang belum siap untuk menerima kehamilan akan meningkatkan keracunan kehamilan dalam bentuk preeklamsia. Sedangkan pada usia 35 tahun atau 
lebih akan terjadi perubahan pada jaringan dan alat reproduksi serta jalan lahir tidak lentur lagi. Pada usia tersebut cenderung didapat penyakit lain dalam tubuh ibu, salah satunya preeklamsia.

\section{Preeklamsia/eklamsia}

terbanyak pada usia 20-24 tahun yang terjadi pada kehamilan pertama. Preeklamsia/eklamsia lebih sering terjadi pada usia muda dan primipara diduga karena adanya suatu mekanisme imunologi disamping endokrin dan genetik dan pada kehamilan pertama pembentukan blocking antibodies terhadap antigen plasenta belum sempurna, yang makin sempurna pada kehamilan berikutnya $^{17}$.

\section{Kadar protein urin ibu hamil trimester II dan III berdasarkan pertambahan berat badan tiap minggu}

Peningkatan berat badan yang cukup pesat terjadi di trimester II dan III, pada periode inilah perlu dilakukan pemantauan ekstra terhadap berat badan ibu hamil. Dalam penelitian ini tidak dijumpai rata-rata pertambahan berat badan ibu hamil trimester II dan III yang lebih dari $1 \mathrm{~kg}$ dan hanya ada $1 \mathrm{ibu}$ hamil yang mengalami rata-rata pertambahan berat badan $1 \mathrm{~kg}$ per minggu sedangkan sebagian besar ibu hamil trimester II dan III yang dijadikan responden sudah memiliki pertambahan berat badan tiap minggu yang baik. Kenaikan total berat badan selama kehamilan, normalnya berkisar antara $12-15 \mathrm{~kg}$, sedangkan memasuki trimester II janin tumbuh pesat dengan pertumbuhan kurang lebih 10 gram per hari, minggu ke 16 sekitar 90 gram, minggu ke 20 sekitar 256 gram, minggu ke 24 sekitar 680 gram, minggu ke 27 sekitar 900 gram. Salah satu risiko penambahan berat badan berlebih bagi ibu hamil adalah preeklamsia (Sanampe, 2014). Hasil pemeriksaan proteinuria pada ibu hamil yang memiliki pertambahan berat badan rata-rata 1 $\mathrm{kg}$ menunjukan hasil positif $++(2)$, sehingga berisiko mengalami preeklamsia. Ibu hamil perlu mendapatkan penanganan lebih lanjut agar tidak terlanjur mengalami preeklamsia.

\section{Kadar protein urin ibu hamil trimester II dan III berdasarkan tekanan darah}


Berdasarkan hasil wawancara pada ibu hamil trimester II dan III di Puskesmas II Denpasar Barat, 10 orang $(25,64 \%)$ ibu hamil memiliki tekanan darah $<110 / 70 \mathrm{mmH}, 27$ orang $(69,23 \%)$ memiliki tekanan darah 110/70 - 140/90 mmHg, dan 2 orang $(5,13 \%)$ ibu hamil memiliki tekanan darah $>140 \mathrm{mmHg}$ serta keduanya memiliki hasil pemeriksaan protein urin positif. Hal ini menunjukan adanya kemungkinan kedua ibu hamil tersebut akan mengalami preeklamsia apabila parameter lain juga menunjukan hasil yang buruk. Pendapat ini sesuai dengan penelitiann yang menyebutkan adanya protein dalam urin ibu hamil di ditandai dengan adanya perubahan warna carik celup. Biasanya disertai dengan adanya edema dan hipertensi yang menandakan ternyadinya preeklamsia $^{19}$.

Ada dua hipertensi dalam kehamilantanpa proteinuria yaitu hipertensi kronik dan hipertensi gestasional serta ada dua hipertensi dalam kehamilan dengan proteinuria yaitu preeklamsia-eklamsia dan hipertensi kronik dengan superimposed preeklamsia.

$\begin{array}{ccr}\text { Kombinasi } & \text { proteinuria } & \text { selama } \\ \text { kehamilan } & \text { secara } & \text { nyata }\end{array}$
meningkatkan risiko mortalitas dan morbilitas perinatal. Hipertensi saja berkaitan dengan peningkatan angka kematian janin sebesar tiga kali lipat. Memburuknya hipertensi terutama apabila disertai proteinuria merupakan pertanda yang buruk. Sebaliknya proteinuria tanpa hipertensi hanya menimbulkan efek keseluruhan yang kecil pada angka kematian bayi.

\section{Kadar protein urin ibu hamil trimester II dan III berdasarkan edema}

Perubahan pokok pada preeklamsia adalah spasmus pembuluh darah disertai dengan retensi garam dan air. Pada beberapa kasus lumen arteriola sangat kecil sehingga hanya dapat dilalui oleh satu sel darah merah. Bila dianggap bahwa spasmus arteriola juga ditemukan di seluruh tubuh, maka terjadinyakenaikan tekanan darah merupakan usaha mengatasi kenaikan tahanan perifer, agar oksigenasi jaringan tercukupi. Kenaikan berat badan dan edema disebabkan oleh penimbunan cairan yang berlebihan ${ }^{20}$. Pada penelitian ini 
ibu hamil yang mengalami edema sebanyak 3 orang dan ketiganya diikuti dengan hasil protein urin positif, sehingga ibu hamil berisiko mengalami preeklamsia. Keadaan ini sesuai dengan penelitian Estina, V.C., Ellya, R.D., dan Rimonta, R.G. periode tahun 2006-2008 yang memperoleh hasil, dari 366 responden yang mengalami preeklamsia dan eklamsia, 322 orang diantaranya mengalami edema.

\section{Kadar protein urin ibu hamil trimester II dan III berdasarkan gravida}

Pada primigravida sering mengalami stress dalam menghadapi persalinan. Stress emosi yang terjadi pada primigravida menyebabkan peningkatan pelepasan corticotropicreleasing hormone (CRH) oleh hipothalamus, yang kemudian menyebabkan peningkatan kortisol. Efek kortisol adalah mempersiapkan tubuh untuk berespon terhadap semua stressor dengan meningkatkan respon simpatis, termasuk respon yang ditujukan untuk meningkatkan curah jantung dan mempertahankan tekanan darah. Pada wanita yang preeklamsia/eklamsia tidak terjadi penurunan sensivitas terhadap vasopeptida tersebut, sehingga peningkatan besar volume darah langsung meningkatkan curah jantung dan tekanan darah ${ }^{20}$

Pada The New England Journal of Medicinetercatat bahwa kehamilan pertama risiko terjadi preeklamsia 3,9\%, kehamilan kedua 1,7\%, dan kehamilan ketiga 1,8\%. Persalinan pertama akan mempunyai risiko terhadap kehamilan, telah banyak terbukti bahwa pada persalinan kedua dan ketiga adalah persalinan yang paling aman. Pada mayoritas primigravida kehamilan minggu ke-28 sampai 32 minggu menunjukkan peningkatan tekanan diastolik sedikitnya $20 \mathrm{mmHg}$ yang bisa sampai mengakibatkan preeklamsia pada kehamilan. Dari hasil wawancara yang dilakukan pada ibu hamil trimester II dan III jumlah primigravida sebanyak 16 orang dan dari 16 orang tersebut yang memiliki hasil pemeriksaan protein urin positif yaitu sebanyak 3 orang, sehingga ketiga ibu hamil ini berisiko mengalami preeklamsia.

Preeklamsia lebih sering terjadi pada kehamilan pertama. Apabila sudah terjadi preeklamsia, sebaiknya dilakukan upaya 
pencegahan untuk tidak menjadi lebih berat. Pengenalan penyakit dan pemeriksaan antenatal memegang peran penting untuk menghindari

\section{SIMPULAN DAN SARAN}

\section{Simpulan}

Berdasarkan hasil penelitian yang telah dilakukan maka dapat disimpulkan:

1. Kadar protein urin pada ibu hamil trimester II dan III di Puskesmas II Denpasar Barat, dari 39 responden masih ditemukan 10 responden yang memiliki hasil pemeriksaan protein urin positif.

2. Dari 10 responden yang positif, dapat dikelompokkan menjadi tujuh sampel $(17,95 \%)$ positif + $(1+)$, dua sampel $(5,13 \%)$ positif

\section{Saran}

\section{Bagi Institusi Puskesmas II Denpasar Barat}

Diharapkan menjadwalkan hari kunjungan khusus untuk ibu hamil, melakukan penyuluhan tentang preeklamsia serta pemeriksaan laboratorium khususnya

\section{Bagi Masyarakat}

Bagi masyarakat khususnya ibu hamil trimester II dan III agar kematian dan faktor risiko yang mungkin terjadi pada ibu maupun janinnya

$++(2+)$ dan satu sampel $(2,56 \%)$ positif $+++(3+)$.

3. Pada pemeriksaan protein urin yang telah dilakukan terhadap 15 orang ibu hamil trimester II diperoleh hasil positif $+(1+)$ sebanyak 3 orang $(20,00 \%)$

4. Pada 24 orang ibu hamil trimester III diperoleh hasil Positif $+(1+)$ sebanyak 4 orang (16,67\%), Positif ++ (2+) sebanyak 2 orang $(8,33 \%)$, dan Positif +++ (3+) sebanyak 1 orang $(8,33 \%)$.

protein urin pada ibu hamil guna mendeteksi dini adanya preeklamsia,sehingga ibu hamil yang berisiko mengalami preeklamsia lebih cepat mendapat penanganan lebih lanjut.

teratur melakukan pemeriksaan kehamilan dan menjaga pola hidup 
yang sehat agar terhindar dari penyakit preeklamsia.

\section{Bagi Peneliti Selanjutnya}

DAFTAR PUSTAKA

1.Dinas Kesehatan Provinsi Bali. Profil Kesehatan Provinsi Bali 2013. Denpasar : Dinas Kesehatan Provinsi Bali. 2014

2.Sutrimah, Mifbakhuddin dan Wahyuni..Faktor-Faktor yang Berhubungan dengan Kejadian Preeklampsia pada Ibu Hamil di Rumah Sakit Roemani Muhammadiyah Semarang. (online) available: http://jurnal.unimus.ac.id/ind ex.php/jurbid/article/downloa d/1383/1437. Diakses tanggal 23 Januari 2016. 2014.

3.Rustiana, W. Asuhan Kebidanan pada Ibu Hamil pada Ny. A $G_{1} P_{0} A_{0}$ Umur 23 Tahun dengan Pre Eklamsi Ringan Di BPS Samsiti Sukoharjo, (online) available:http://stikeskusuma husada.ac.id/digilib/downloa
Bagi peneliti selanjutnya diharapkan sampel da karakteristik penelitian lebih banyak sehingga data hasil penelitian lebih representatif.

d.php?id=86, diakses tanggal 26 Januari 2016. 2012.

4.Syuhada,dkk..Korelasi Proteinuria Metode Rasio AlbuminKreatinin Urin dengan Metode Kromatografi pada Preeklamsi. (online) available:

http://journal.fk.unpad.ac.id/i ndex.php/mkb/article/viewFil e/139/pdf_43. Diakses tanggal 23 Januari 2016. 2014.

5.Estina, V.C., Ellya, R.D., Rimonta, R.G. Karakteristik Penerita Preeklamsia dan Eklamsia yang Dirawat Inap di Rumah Sakit Immanuel Bandung Periode Tahun 2006 - 2008. Bandung: Fakultas Kedokteran, Universitas Kristen Maranatha. 2010 6.Puswoastuti, E. dan E.S. Walyuni. Ilmu Obstetri dan Ginekologi Sosial Bagi Kebidanan. 
Yogyakarta: PT. Pustaka Baru. 2015.

7.Febrianti,I. Gambaran Hasil

Pemeriksaan Protein Urin pada Ibu Hamil Trimester III di Rumah Sakit Bersalin Ibu Semarang. (online) available: http://digilib.unimus.ac.id.ph p?mod=browse\&op=read\&id $=$ =jtptunimusgdl-sl-2008-

indahfebri-244. Diakses tanggal 23 Januari 2016. 2008.

8. Dinas Kesehatan Kota Denpasar, Laporan Kegiatan KIA. Denpasar : Dinas Kesehatan Kota Denpasar. 2012.

9.Notoatmodjo,S.Metodologi

Penelitian. Edisi revisi cetakan kedua.Jakarta : PT. Rineka Cipta. 2012.

10.Sugiono. Metode Penelitian Kuantitatif dan $R \& D$. Bandung: Alfabeta. 2013.

11.Radjamuda, $\mathrm{N}$ dan Agnes, $\mathrm{M}$. Faktor-Faktor Risiko Yang Berhubungan Dengan Kejadian Hipertensi Pada Ibu Hamil Di Poli Klinik Obs-Gin Rumah Sakit Jiwa Prof. Dr. V. L. Ratumbuysang Kota Manado. Manado:
Jurusan Kebidanan STIKES Muhammadiah Manado \& Jurusan Kebidanan Poltekkes Kemenkes Manado. 2014. 12.Karima, N. M., R. Machmud, Y. Affiliasi. Hubungan Faktor Risiko dengan Kejadian PreEklampsia Berat di RSUP Dr. M. Djamil Padang. Padang: Fakultas Kedokteran Universitas Andalas Padang. 2015.

13.Dharma, R., N. Wibowo, H.P.T., Raranta. Disfungsi Endotel pada Preeklampsia. Jakarta: Departemen Patologi Klinik Fakultas Kedokteran Universitas Indonesia \& Departemen Obstetri dan Ginekologi Fakultas Kedokteran Universitas Indonesia. 2015.

14.Afandi, D.W.S., Hanif, M. N., dan Adriani. Hubungan Preeklampsia dan Hpertensi Gestasional dengan Berat Badan Lahir Bayi di RSUD Raden Mattaher Jambi Tahun 2012. Jambi: Fakultas Kedokteran dan Ilmu Kesehatan, Universitas Jambi 2012. 
15.Kasmian. Gambaran Hasil bekrjasama dengan politeknik pemeriksaan Proteinuria Kesehatan Kemenkes pada Ibu Hamil Trimester II Makassar. 2013.

di Bidan Praktek Swasta Citra Mulia Kudus. (online) available:http://digilib.unimu s.ac.id/gdl.php?mod=browse $\& o p=$ read\&id=jtptunimugdlk asmiangoc5690\&PHPSESSI $\mathrm{D}=\mathrm{abcc} 70 \mathrm{a} 13661$ fafle 239259 ec951. Diakses tanggal 24 Januari 2016. 2010.

16.Astuti, S. F. Faktor-Faktor yang Berhubungan Dengan Kejadian Preeklamsia Kehamilan Di Wilayah Kerja Puskesmas Pamulang Kota Tangerang Selatan Tahun 2014-2015. Jakarta. 2015. Universitas Syarif Hidayatullah

17.Windaryani, Y., H. S. Dode dan A. Mallo. Hubungan Antara 19.Minarti, S., A. E. Suryandari dan M. Retnowati. Hubungan Penambahan Berat Badan Dengan Kejadian Pre Eklampsi Pada Ibu Hamil di RSUD Prof. Dr. Margono Soekardjo Purwokerto Tahun 2011. Purwokerto: Akademi kebidanan YLPP Purwokerto. 2011.

20..Minarti, S., A. E. Suryandari dan M. Retnowati. Hubungan Penambahan Berat Badan Dengan Kejadian Pre Eklampsi Pada Ibu Hamil di RSUD Prof. Dr. Margono Soekardjo Purwokerto Tahun 2011. Purwokerto: Akademi kebidanan YLPP Purwokerto. 2011.

Primigravida/Multigravida

Dengan Angka Kejadian

Preeklamsia/Eklamsia di RSKDIA Siti Fatimah Makassar. Makasar: stikes Nani Hasanuddin Makassar 